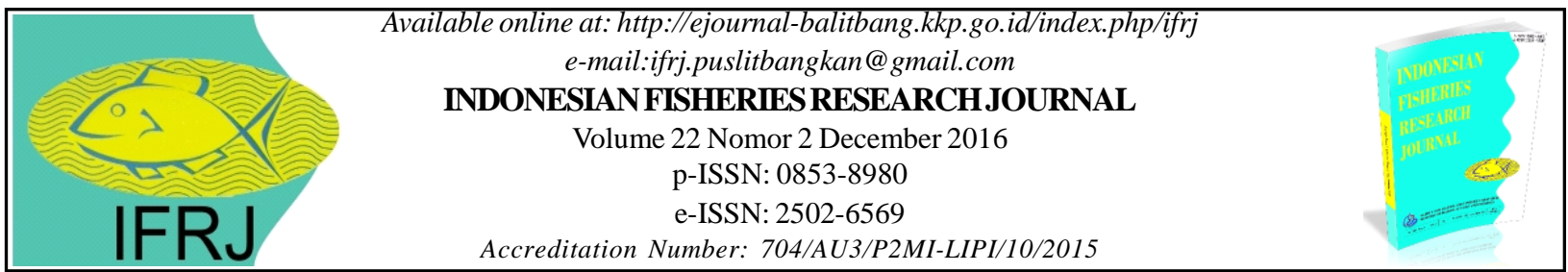

\title{
THE INFLUENCE OF SWIMMING LAYER AND SUB-SURFACE OCEANOGRAPHIC VARIABLES ON CATCH OF ALBACORE (Thunnus alalunga) IN EASTERN INDIAN OCEAN
}

\author{
Fathur Rochman*1, Widodo Pranowo ${ }^{2}$ and Irwan Jatmiko' \\ ${ }^{1}$ Research Institute for Tuna Fisheries, Jl. Mertasari No. 140, Sidakarya, Denpasar Selatan, Denpasar, Bali - 80224. Indonesian \\ ${ }^{2}$ Research and Development Center for Marine \& Coastal Resources, Jl. Pasir Putih II Ancol Timur, Jakarta. Indonesian \\ Received; May 08-2015 Received in revised from Nov 29-2016; Accepted Nov 29-2016
}

\begin{abstract}
This study was highlighted the contenxt of albacore's number catch, swimming layer and subsurface oceanographic variables (SSOV) at Eastern Indian Ocean include temperature, dissolved oxygen, salinity, nitrate, phosphate and silicate. Hopefully the information would be useful for the longliners to understand the ALB behaviour, environment and the best techniques on how to catch this fish. Data in this study were based on the Research Institute for Tuna Fisheries (RITF) observer program in Benoa from 2010-2013. Data analysis was base on primary data and secondary data. Primary data are albacore's (ALB) swimming layer data which are measured by minilogger. Secondary data is SSOV data which extracted from World Ocean Atlas 2009 (WOA09). The results show that the optimum catch of albacore occurred at depth of 118 to $291 \mathrm{~m}$ with the average temperature between 12.41-20.47 ${ }^{\circ} \mathrm{C}$, dissolved oxygen $3.24-4.68 \mathrm{ml} / \mathrm{l}$, salinity $34.78-35.01 \mathrm{psu}$, nitrate $6.78-17.50 \mu \mathrm{mol} /$ I, phosphate $0.62-1.27 \mu \mathrm{mol} / \mathrm{l}$ and silicate $10.06-24.77 \mu \mathrm{mol} / \mathrm{l}$. The highest catch of ALB was mostly at depth of $156 \mathrm{~m}$ (hook number 2 and 11 ) with the average temperature $18.71^{\circ} \mathrm{C}$, dissolved oxygen $4.68 \mathrm{ml} / \mathrm{l}$, salinity $34.78 \mathrm{psu}$, nitrate $10.71 \mu \mathrm{mol} / \mathrm{l}$, phosphate $0.86 \mu \mathrm{mol} / \mathrm{l}$ and silicate $15.95 \mu \mathrm{mol} / \mathrm{l}$. The highest influence of swimming layer and sub-surface oceanographic variable to the number of ALB catch happened at depth of $291 \mathrm{~m}$ of ALB swimming layer with coefficient correlation $(r)$ of 0.934 and determination coefficient $\left(R^{2}\right)$ of 0.872 . The lowest influence of swimming layer and sub-surface oceanographic variable to the number of ALB catch happened at depth of $156 \mathrm{~m}$ of albacore swimming layer with coefficient correlation $(r)$ of 0.528 and determination coefficient $\left(R^{2}\right)$ of 0.279 . The relationship between swimming layer and sub-surface oceanographic variable on catch of ALB tuna was low $(<0.500)$.
\end{abstract}

\section{Keywords: Swimming layer; sub surface oceanographic variable; albacore; Eastern Indian Ocean}

\section{INTRODUCTION}

Albacore (ALB) is a temperate tuna, living mainly in the mid oceanic gyres of the Pacific, Indian and Atlantic Oceans (IOTC, 2014). In the Atlantic, their geographic limits are from $45-50^{\circ} \mathrm{N}$ and $30-40^{\circ} \mathrm{S}$, while in the Indian Ocean, it's distribution ranges from $5^{\circ} \mathrm{N}$ to $40^{\circ} \mathrm{S}$ with adults occurring from $5^{\circ} \mathrm{N}$ to $25^{\circ} \mathrm{S}$ (ISSF, 2014). According to IOTC, (2014), albacore is a highly migratory species, swimming for long distances during its lifetime (Chen et al., 2005). The ALB habit like that, because they are capable of thermo regulation, has high metabolic rate, and advance cardiovascular and blood/gas exchange systems. In the Pacific Ocean, migration, distribution availability, and vulnerability of ALB are strongly influenced by oceanographic conditions, especially oceanic fronts. Pre-adults ( $2-5$ year old albacore) appear to be more migratory than adults.

ALB tuna has vertical and horizontal movement (William et al., 2014). The distribution and the abundant of ALB, are greatly influenced by oceanographic variables, such as temperature, swimming layers (depth of water), and nutrients (William et al., 2014). The information of ALB distribution is very important to determine the successful of tuna catch operation (Barata et al., 2011).

The main problem in catching ALB species is unknown its swimming layer stratification and accompanying phenomena related to the sub surface oceanographic variable (environment). This study 
describes the impact and correlation of swimming layer and sub-surface oceanographic variables (SSOV) on catch of ALB in Eastern Indian Ocean based on the observer data (as fishing index) and oceanographic data (as predictive index). The oceanographic data are collected by the extraction of World Ocean Atlas 2009. The purpose of this study is give a brief information to the Indonesian tuna longliner on ALB behavior, the best technique and methods to catch ALB.

\section{MATERIALS AND METHODS Study Area}

This study area of ALB based on result of onboard observer program in 2010-2013. The ALB fishing area caught by tuna longline fisheries was between $0-33^{\circ} \mathrm{S}$ and $85-125^{\circ} \mathrm{E}$. The ALB fishing areas are mostly in outside Indonesian Exclusive Economic Zone (EEZ) as presented in Figure 1.

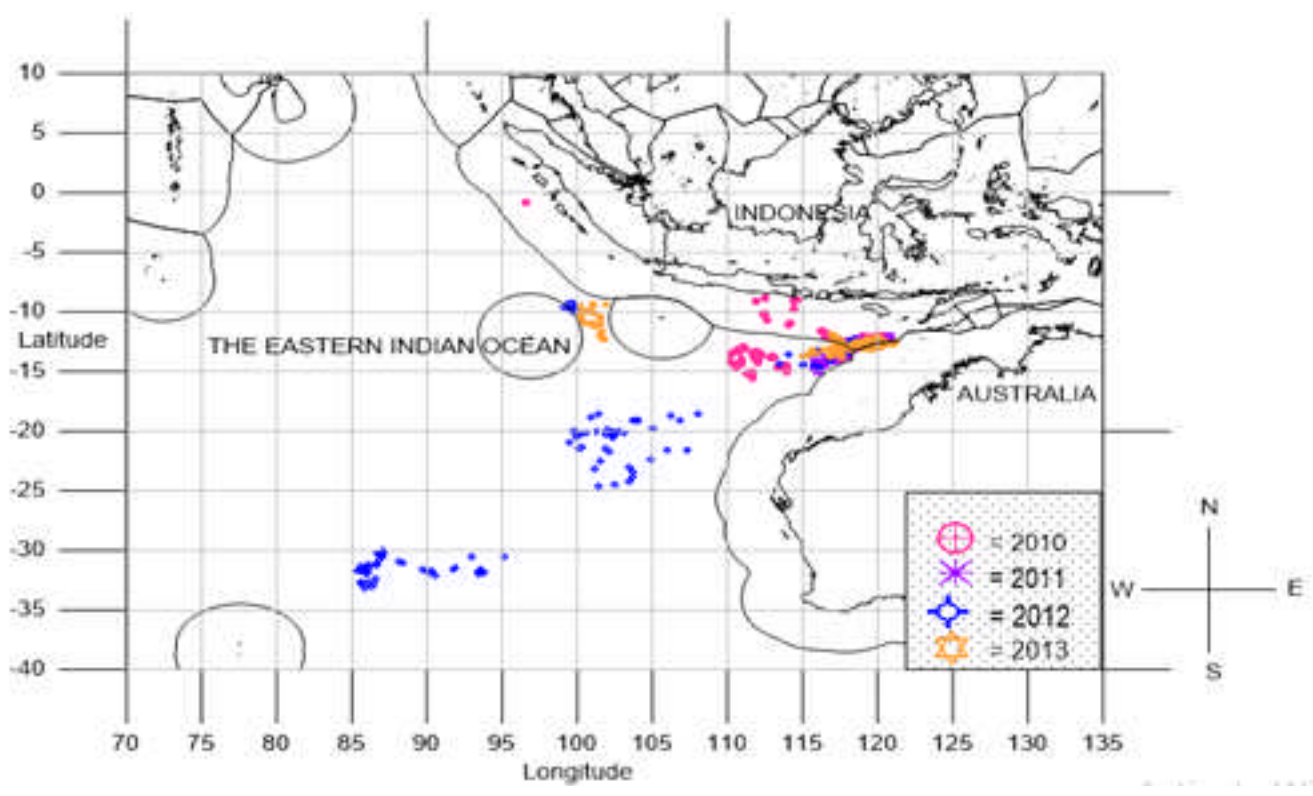

Figure 1. Map of the study area of ALB in Eastern Indian Ocean by Indonesian Tuna Longline fleets sets from 2010-2013.

\section{Data Collection}

Data analyzed were obtained from onboard observer program on commercial tuna longline fleets at Benoa-Bali in period of March 2010-October 2013, with 25 times fishing trips (2.338 active fishing days), catch and effort data were collected.

In this study, some miniloggers (SP2T-1200 from NKE Instrumentation) were used to know ALBs hook depth. Minilogger were fitted at the end of branch line and replaced the hook. Radio data pencil was used to transfer data from minilogger to WinMemo program in the computer. The data from WinMemo was transferred to Microsoft excel program to be analyzed and presented as graphical form.

The material used in this study was sub-surface oceanographic variables (SSOV) derived from Word Ocean Atlas 2009 (WOA09) extraction. WOA09 is a set of objectively analyzed ( $1^{\circ}$ grid) climatological fields of in situ temperature, salinity, dissolved oxygen, apparent oxygen utilization includes associated statistical fields of observed oceanographic profile data interpolated to standard depth level on both $1^{\circ}$ grid and $5^{\circ}$ grid. Data processing was conducted at marine and coastal laboratory of Research and Development Center for Marine and Coastal Resources (RDCMCR), Research and Development Agency for Marine and Fisheries, Ministry of Marine Affairs and Fisheries. A free ware Ocean Data View ver. 4.5.3.was use to collect the environmental data from the satellite.

\section{Data Analysis}

Four SSOV variables are temperature, dissolved oxygen, salinity and nutrient (nitrate, phosphate and silicate). The depths used in the analysis are based on the measurement of minilogger (swimming layer of ALB) i.e. $118 \mathrm{~m}, 156 \mathrm{~m}, 215 \mathrm{~m}, 291 \mathrm{~m}, 319 \mathrm{~m}$ and $341 \mathrm{~m}$ depths (Figure 2 ). 


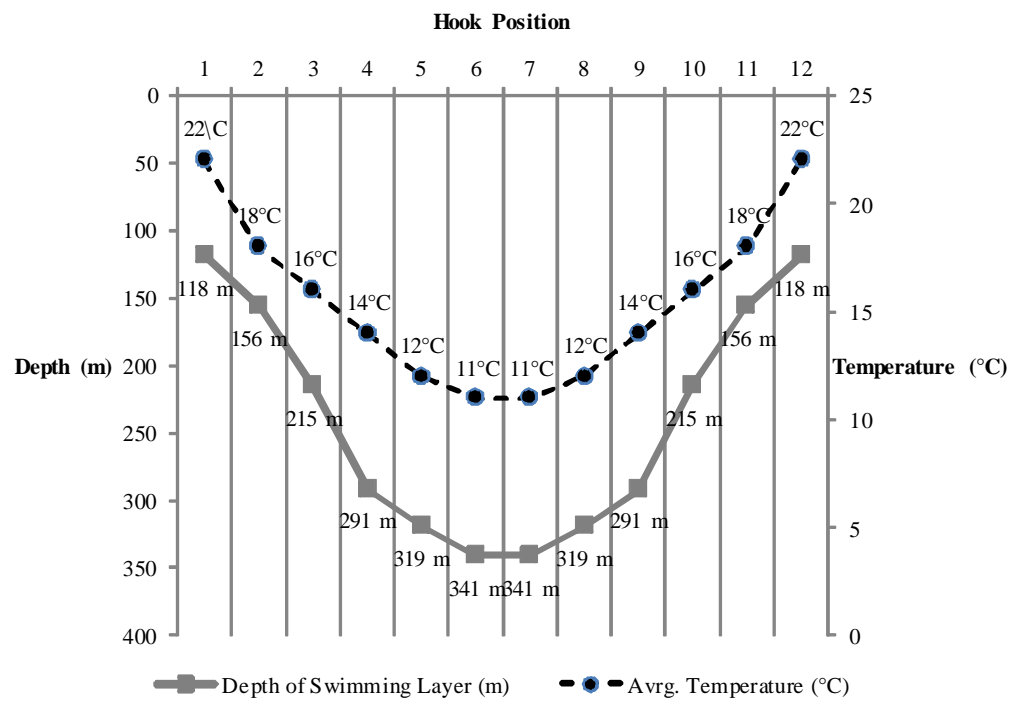

Figure 2. The depth of ALB swimming layer, hook position and average temperature $\left({ }^{\circ} \mathrm{C}\right)$ measured using minilogger from the Research Institute for Tuna Fisheries (RITF) observer program data ranged from 2010-2013.

Prior to analyses, we used single regression using polynomial equation was used i.e.:

$\mathrm{Y}=a x^{2}+b x+c$

where,

$Y=$ catches of $A L B$

$\mathrm{X}=$ sub-surface oceanographic variables in depth of $(118 \mathrm{~m}, 156 \mathrm{~m}, 215 \mathrm{~m}, 291 \mathrm{~m}, 319 \mathrm{~m}$, and $341 \mathrm{~m})$

Whereas multiple regressions using linier equation:

$Y=a+b x_{1}+c x_{2}+d x_{3}+e x_{4}+f x_{5}+g x_{6}$

where,

$\mathrm{Y} \quad=$ catches of $\mathrm{ALB}$

a $\quad$ constanta

$\mathrm{b}, \mathrm{c}, \mathrm{d}, \mathrm{e}=$ coefficient

$\mathrm{x}_{1}=$ temperature

$x_{2} \quad=$ dissolved oxygen

$\mathrm{x}_{3} \quad=$ salinity

$\mathrm{x}_{4} \quad=$ nitrate

$x_{5} \quad=$ phosphate

$\mathrm{x}_{6} \quad=$ silicate

According to Hadi (2004), in research methodology correlation coefficient between two factors always moved between $-1 \mathrm{e}$ " $\mathrm{r}$ " 1 , the negative correlation moved between -1 to 0 and the positive correlation moved between 0 to 1 (Table 1 ).
Table 1. The classification of correlation coefficient value

\begin{tabular}{|c|c|}
\hline Correlation Coefficient & \\
\hline$(\mathrm{r})$ & Interpretation \\
\hline $0.8-1$ & high \\
\hline $0.6-0.8$ & high enough \\
\hline $0.4-0.6$ & rather low \\
\hline $0.2-0.4$ & low \\
\hline $0.0-0.2$ & very low \\
\hline
\end{tabular}

Source: Hadi (2004)

\section{RESULTS AND DISCUSSION}

Results

\section{Swimming Layer and Oceanographic Parameters}

The highest catch of ALB was mostly at depth of $156 \mathrm{~m}$ (hook number 2 and 11 ) in the water condition characterized with the average temperature $18.71^{\circ} \mathrm{C}$, dissolved oxygen $4.68 \mathrm{ml} / \mathrm{l}$, salinity $34.78 \mathrm{psu}$, nitrate $10.71 \mu \mathrm{mol} / \mathrm{l}$, phosphate $0.86 \mu \mathrm{mol} / \mathrm{l}$ and silicate $15.95 \mu \mathrm{mol} / \mathrm{l}$. The optimum catch of ALB occurred at depth of 118 to $291 \mathrm{~m}$ with the average temperature between $12.41-20.47^{\circ} \mathrm{C}$, dissolved oxygen $3.24-4.68$ $\mathrm{ml} / \mathrm{l}$, salinity $34.78-35.01 \mathrm{psu}$, nitrate $6.78-17.50 \mu$ $\mathrm{mol} / \mathrm{l}$, phosphate $0.62-1.27 \mu \mathrm{mol} / \mathrm{l}$ and silicate 10.06 $24.77 \mu \mathrm{mol} / \mathrm{l}$ (Table 2). 
Tabel 2. The relationship between swimming layer, number of catch and SSOV of ALB catch in Eastern Indian Ocean.

\begin{tabular}{cccccccc}
$\begin{array}{c}\text { Swimming Layer No. of Catch } \\
(\mathrm{m})\end{array}$ & $(\mathrm{pcs})$ & $\begin{array}{c}\text { Temperature } \\
\left({ }^{\circ} \mathrm{C}\right)\end{array}$ & $\begin{array}{r}\text { Dissolved Oxygen } \\
(\mathrm{m} / \mathrm{l})\end{array}$ & $\begin{array}{c}\text { Salinity } \\
(\mathrm{psu})\end{array}$ & $\begin{array}{c}\text { Nitrate } \\
(\mu \mathrm{mo} / \mathrm{N})\end{array}$ & $\begin{array}{c}\left.\mathrm{N}_{3}\right) \\
(\mu \mathrm{mo} / \mathrm{l})\end{array}$ & $\begin{array}{c}\text { Phosphate } \\
(\mu \mathrm{mo} / \mathrm{l})\end{array}$ \\
\hline 118 & 416 & 20.47 & 3.89 & 34.83 & 6.78 & 0.62 & 10.06 \\
$\mathbf{1 5 6}$ & $\mathbf{5 1 1}$ & $\mathbf{1 8 . 7 1}$ & $\mathbf{4 . 6 8}$ & $\mathbf{3 4 . 7 8}$ & $\mathbf{1 0 . 7 1}$ & $\mathbf{0 . 8 6}$ & $\mathbf{1 5 . 9 5}$ \\
215 & 417 & 15.66 & 3.24 & 35.01 & 15.39 & 1.15 & 21.80 \\
291 & 331 & 12.41 & 3.55 & 34.95 & 17.50 & 1.27 & 24.77 \\
319 & 28 & 11.50 & 2.69 & 34.81 & 23.44 & 1.66 & 33.19 \\
341 & 13 & 11.10 & 2.68 & 34.70 & 25.30 & 1.72 & 37.30 \\
\hline
\end{tabular}

\section{Correlation Analysis between Catch and SSOV}

The correlation between catches of ALB and SSOV was moderate $(>0.500)$ and the highest correlation coefficient found at $291 \mathrm{~m}$ of ALB swimming layer (Table 3).

The single regression analysis between the number of catch and specific SSOV such as temperature, dissolved oxygen, salinity, nitrate, phosphate and silicate was presented in Table 4. The relationship between the number of catch and specific SSOV was low $(<0.500)$. The highest correlation is temperature (mean $r=0.369$ ) followed by salinity (mean $r=0.212$ ), dissolved oxygen (mean $r=0.176)$, silicate (mean $r=$ 0.170 ), phosphate (mean $r=0.157$ ) and nitrate (mean $r=0.152)$.

Table 3. Multiple regression analysis of ALB in Eastern Indian Ocean with different swimming layer.

\begin{tabular}{clccc}
\hline $\begin{array}{c}\text { Swimming Layer } \\
(\mathbf{m})\end{array}$ & Polynomial Equation & $\mathbf{n}$ & $\mathbf{r}$ & $\mathbf{R}^{2}$ \\
\hline 118 & $\mathrm{Y}=2872.25-12.78 \mathrm{X}_{1}-5.01 \mathrm{X}_{2}-72.42 \mathrm{X}_{3}-2.41 \mathrm{X}_{4}-37.83 \mathrm{X}_{5}-0.54 \mathrm{X}_{6}$ & 18 & 0.787 & 0.619 \\
156 & $\mathrm{Y}=2124.78-8.50 \mathrm{X}_{1}-0.12 \mathrm{X}_{2}-54.20 \mathrm{X}_{3}-2.57 \mathrm{X}_{4}-76.87 \mathrm{X}_{5}+2.35 \mathrm{X}_{6}$ & 21 & 0.528 & 0.279 \\
215 & $\mathrm{Y}=274.88-12.17 \mathrm{X}_{1}+17.33 \mathrm{X}_{2}-3.26 \mathrm{X}_{3}-3.98 \mathrm{X}_{4}-59.93 \mathrm{X}_{5}+5.62 \mathrm{X}_{6}$ & 22 & 0.763 & 0.582 \\
291 & $\mathrm{Y}=5990.55+21.36 \mathrm{X}_{1}+95.230 \mathrm{X}_{2}-192.70 \mathrm{X}_{3}-5.94 \mathrm{X}_{4}+220.89 \mathrm{X}_{5}-0.26 \mathrm{X}_{6}$ & 11 & 0.934 & 0.872 \\
319 & $\mathrm{Y}=5990.55+21.36 \mathrm{X}_{1}+95.230 \mathrm{X}_{2}-192.70 \mathrm{X}_{3}-5.94 \mathrm{X}_{4}+220.89 \mathrm{X}_{5}-0.26 \mathrm{X}_{6}$ & 8 & 0.747 & 0.557 \\
\hline
\end{tabular}

Note: $X_{1}=$ temperature, $X_{2}=$ dissolved oxygen, $X_{3}=$ salinity, $X_{4}=$ nitrate, $X_{5}=$ phosphate, $X_{6}=$ silicate, $\mathrm{Y}=$ catches of $\mathrm{ALB}, \mathrm{r}=$ correlation coefficient, $\mathrm{R}^{2}=$ coefficient of determination

Table 4. Single regression analysis between number of catch and specific oceanographic variable at different swimming layer

\begin{tabular}{|c|c|c|c|c|c|c|c|}
\hline \multirow[b]{2}{*}{$\begin{array}{l}\text { Swimming Layer } \\
\text { (m) }\end{array}$} & \multicolumn{6}{|c|}{ Sub -Surface Oceanographic Variable } & \multirow[b]{2}{*}{ Annotation } \\
\hline & $\begin{array}{c}\text { Temperature } \\
\left({ }^{\circ} \mathrm{C}\right)\end{array}$ & $\begin{array}{l}\text { Disolved } \mathrm{O}_{2} \\
(\mathrm{ml} / \mathrm{l})\end{array}$ & $\begin{array}{l}\text { Salinity } \\
\text { (psu) }\end{array}$ & $\begin{array}{c}\text { Nitrate }\left(\mathrm{NO}_{3}{ }^{-}\right) \\
(\mu \mathrm{mol} / \mathrm{l})\end{array}$ & $\begin{array}{l}\text { Phosphate } \\
(\mu \mathrm{mol} / \mathrm{l})\end{array}$ & $\begin{array}{r}\text { Silicate } \\
(\mu \mathrm{mol} / \mathrm{l})\end{array}$ & \\
\hline \multirow{3}{*}{$118 \mathrm{~m}$} & $Y=732.79-72.315 X+1.809 X X$ & $Y=194.02-95.68 X+12.59 X^{2}$ & $Y=-362.95+11.08 X$ & $\mathrm{Y}=27.81+0.51 \mathrm{X}-1.27 \mathrm{X}^{2}$ & $Y=30.66-12.13 X$ & $Y=35.03-1.37 X+0.015 X^{2}$ & Polynomial Equatior \\
\hline & 0.551 & 0.452 & 0.246 & 0.295 & 0.143 & 0.255 & r \\
\hline & 0.304 & 0.204 & 0.061 & 0.087 & 0.200 & 0.065 & $\mathrm{R}^{2}$ \\
\hline \multirow{3}{*}{$156 \mathrm{~m}$} & $Y=212.09-17.75 X+0.409 X^{2}$ & $Y=16.93+2.96 X-0.11 X^{2}$ & $Y=33.11-0.252 X$ & $Y=7.60+5.67 X-0.32 X^{2}$ & $Y=8.39+81.18 X-62.10 X^{2}$ & $Y=21.94+1.36 X-0.064 X^{2}$ & Polynomial Equatior \\
\hline & 0.173 & 0.138 & 0.003 & 0.160 & 0.224 & 0.090 & $\mathrm{r}$ \\
\hline & 0.030 & 0.019 & 0.000 & 0.026 & 0.050 & 0.008 & $\mathrm{R}^{2}$ \\
\hline \multirow{3}{*}{$215 \mathrm{~m}$} & $Y=386.21-38.93 X+0.98 X^{2}$ & $=369.82-202.58 X+26.94 X^{\prime}=$ & $9162.98-501.021 X+6.8$ & $X Y=7.86+3.52 X-0.15 X^{2}$ & $Y=-29.39+125.27 X-62.91 X^{i}$ & $Y=47.48-5.74 X+0.17 X^{2}$ & Polynomial Equatior \\
\hline & 0.387 & 0.003 & 0.160 & 0.078 & 0.015 & 0.148 & $\mathrm{r}$ \\
\hline & 0.150 & 0.000 & 0.026 & 0.006 & 0.000 & 0.022 & $\mathrm{R}^{2}$ \\
\hline \multirow{3}{*}{$291 \mathrm{~m}$} & $Y=235.12-24.98 X+0.67 X^{2}$ & $l=349.52-181.05 X+23.18 X$ & $Y=1095.79-30.496 X$ & $Y=-1.35+5.77 X-0.18 X^{2}$ & $Y=27.09-19.19 X+14.53 X^{2}$ & $Y=50.90-5.31 X+0.13 X^{2}$ & Polynomial Equatior \\
\hline & 0.347 & 0.107 & 0.356 & 0.004 & 0.226 & 0.236 & $\mathrm{r}$ \\
\hline & 0.121 & 0.012 & 0.127 & 0.000 & 0.510 & 0.056 & $\mathrm{R}^{2}$ \\
\hline \multirow{3}{*}{$319 \mathrm{~m}$} & $Y=133.56-19.64 X+0.72 X^{2}$ & $Y=-12.71+12.09 X-2.06 X^{2}$ & $Y=234.80-6.64 X$ & $Y=-5.07+0.67 X-0.01 X^{2}$ & $Y=-15.43+27.22 X-8.97 X^{2}$ & $Y=-2.01+0.519 X-0.01 X^{2}$ & Polynomial Equatior \\
\hline & 0.387 & 0.181 & 0.297 & 0.223 & 0.176 & 0.119 & $\mathrm{r}$ \\
\hline & 0.150 & 0.033 & 0.088 & 0.050 & 0.031 & 0.014 & $\mathrm{R}^{2}$ \\
\hline
\end{tabular}




\section{Discussion}

\section{Swimming Layer and Oceanographic Parameters}

Depth of the waters is devided into 3 layers i.e. surface layer (homogeneous layer), thermocline layer (temperature dropped sharply), and under layer (cold layer) (Latumeten et al., 2013). Tuna and tuna like species fisheries in Eastern Indian Ocean are closely linked with thermocline layer. Large pelagic fishes tend to live in thermocline layer and the area below the thermocline layer (Song et al., 2007). According to Nontji (1993), thermocline is a deep layer of the waters where the temperature decreases rapidly with the depth. The absolute value of vertical temperature decrease in standard thermocline layer was e" 0.05 ${ }^{\circ} \mathrm{C} \mathrm{m}^{-1}$ depth (Bureau of technical supervision of the P.R of China, 1992).

The current study indicates that the majority of ALB swimming layer was in thermocline water with depth of 118 to $291 \mathrm{~m}$ (Table 2). The highest catch of ALB is conducted at $156 \mathrm{~m}$ swimming layer because this layer has a compatible temperature (mean \pm $19^{\circ} \mathrm{C}$ ), compatible salinity (mean $\pm 34.78 \mathrm{psu}$ ) and sufficient oxygen dissolved (mean $\pm 4.68 \mathrm{ml} / \mathrm{l}$ ). The result of this study in accordance with Nugraha \& Triharyuni, (2009), who stated that ALB in Indian Ocean was caught at depth of 150-199.9 m. This study also indicated that temperature, dissolved oxygen, salinity and the availability of prey are greatly sufficient to ALB life. This study shows that the optimum temperature range was from 12.41 to 20.47 and the optimum dissolved oxygen was $>2.69 \mathrm{ml} / \mathrm{l}$. Lehodey (2002) stated that the minimum oxygen requirement for ALB is about $2 \mathrm{ml} / \mathrm{l}$ with the optimum temperature range from $15-25^{\circ} \mathrm{C}$. Chen et al. (2005) stated that ALB especially mature ALB (spawning and non-spawning ALB) are greatly influenced by sea surface temperature (SST), temperature at depth of $100 \mathrm{~m}$ (Temp_100), sea surface salinity (Sal_0), and dissolved oxygen at depth of $200 \mathrm{~m}$ (DO_200). The optimum CPUE Catch per Unit of Effort of ALB occurred at the average of $(S S T) 25^{\circ} \mathrm{C},($ Temp_100) $21.2^{\circ} \mathrm{C}$, (Sal_0) 35psu and (DO_200) $5.42 \mathrm{ml} / \mathrm{l}$.

The optimum swimming layer of ALB (Table 2) also occurred in the area of photic zone or pelagic zone (0-200 $\mathrm{m}$ depth) where the intensity of sunlight is enough for the photosynthesis process (Nybakken, 1992). This area also containts high primary productivity with temperature ranging between 15.66- $20.47^{\circ} \mathrm{C}$, dissolved oxygen $>3 \mathrm{ml} / \mathrm{l}$, average of salinity $\pm 35 \mathrm{psu}$, nitrate $6.78-15.39 \mu \mathrm{mol} / \mathrm{l}$, phosphate 0.62 $1.15 \mu \mathrm{mol} / \mathrm{l}$ and silicate $10.06-21.80 \mu \mathrm{mol} / \mathrm{l}$. This study is in accordance with Guntara, (2004), who stated that photic area has high primary productivity with temperature range $10-28^{\circ} \mathrm{C}$, salinity $37-32$ per mil, dissolved oxygen $3.5-7 \mathrm{ml} / \mathrm{l}$ and nutrient content (phosphate) 0-30 mg/m $\mathrm{m}^{3}$. The photosynthesis process followed by the availability of plankton (phytoplankton and zooplankton) that serves as food for small fish and small fishes in their turn serve as food for big fish.

Horizontally, ALB tuna is capable of residing within an area of approximately $300-400 \mathrm{~km}^{2}$ for periods of at least days to weeks, and also capable to moving for larger distances $(>1,000 \mathrm{~km})$ within periods of weeks (William et al., 2014). Migration over $1,000 \mathrm{~km}$ mostly is involved by seasonal migration (Cosgrove et al., 2014). Tuna seasonal migration is caused by seasonal oscillation (EI Nino and La Nina) characterized by a difference sea surface temperature (Syamsuddin et al., 2013). Vertically, ALB tuna can move to seek the preferred area. According to Domokos et al. (2007), ALB tuna spends their time in deeper and cooler waters during the day and shallow waters during the night. ALB tuna is thought to use physiological thermoregulation to maintain a stable body temperature at approximately $20{ }^{\circ} \mathrm{C}$ in water temperatures between 11.5 and $18.0^{\circ} \mathrm{C}$ (Graham \& Dickson, 1981). Below $11.5^{\circ} \mathrm{C}$, the body temperature of albacore tuna has been observed to decline, and in response, individuals have been observed to modify their behavior, moving vertically into warmer water, to raise the body temperature. The study in New Zealand water indicated that ALB did not enter water less than $12{ }^{\circ} \mathrm{C}$. In addition, vertical movement of ALB also related to the abundance of prey such as krill, anchovy, squid and others small pelagic fish (William et al., 2014).

\section{Correlation Analysis between Catch and SSOV}

The information on relationship between the number of catch and sub-surface oceanographic variables (SSOV) is conducted using regression analysis. The relationship will be higher if the correlation coefficient (r) and determination coefficient $\left(R^{2}\right)$ are close to one (1). Based on single regression analysis between SSOV and the number of catch for all season in Eastern Indian Ocean, it found that the highest coefficient correlation ( $r$ ) of 0.934 and determination 
coefficient $\left(R^{2}\right)$ of 0.872 were contained in ALB swimming layer $291 \mathrm{~m}$ depth. The lowest coefficient correlation $(r)$ of 0.528 and the lowest determination coefficient $\left(R^{2}\right)$ of 0,279 were found in ALB swimming layer $156 \mathrm{~m}$ depth (Table 3). It means that the relationship between SSOV and the number of catch in depth of $291 \mathrm{~m}$ is high. Determination coefficient $\left(R^{2}\right)$ of 0,872 means that $87,2 \%$ of SSOV in depth of $291 \mathrm{~m}$ affected the number of ALB catches. The specific SSOV which influenced the number of ALB catches at depth of $291 \mathrm{~m}$ were temperature $(r=0,347$ and $\left.R^{2}=0,121\right)$, salinity $\left(r=0,356\right.$ and $\left.R^{2}=0,127\right)$ (Table 4). The average temperature and salinity at depth of 291 were $12,41^{\circ} \mathrm{C}$ and 34,95 psu. Temperature variable is a key factor of ALB behavior. According to William et al. (2014), based on ALB tuna tagged in South Pacific Ocean, ALB did not enter the water below $12^{\circ} \mathrm{C}$. Thus, the slightest change of temperature variable will be followed by a significant change of ALB catches. In this study, sub- surface salinity and dissolved oxygen were not differentiating factor because salinity range was stable at 34-35 psu and dissolved oxygen $>2 \mathrm{ml} / \mathrm{l}$. The optimal salinity for ALB was 33-35 psu and the minimum oxygen requirement is about $2 \mathrm{ml} / \mathrm{l}$ (Foreman,1980). ALB tends to choose more appropriate salinity with the osmotic pressure of their bodies. The change in salinity will stimulate ALB to migrate (horizontal and vertical) to the place of a suitable salinity with the osmotic pressure of their bodies. The high metabolic activity of swimming ALB requires the support of circulating system capable of delivering high volume of blood and large quantity oxygen to the whole of their bodies (Lai et al., 1987).

In swimming layer of $156 \mathrm{~m}$ depth, the relationship between SSOV and the number of ALB catches was low $\left(r=0.528\right.$ and $\left.R^{2}=0.279\right)$ although the increasing of ALB catch number occurred. At depth of $156 \mathrm{~m}$, the average of SSOV was in optimal condition (Table 3) (temperature $\pm 18,71^{\circ} \mathrm{C}$, dissolved oxygen $\pm 4,68$ $\mathrm{ml} / \mathrm{l}$, salinity $\pm 34,78$, nitrate \pm 10.71 , phosphate $\pm 0,86$ and silicate $\pm 15,95)$. Besides that, this swimming layer has a sufficient sunlight for photosynthesis process and lead to high primary productivity. The increasing of primary productivity is followed by the increasing of ALB prey such as squid, krill and others small pelagic fish. This causes the number of ALB catch at this swimming layer steady increase even though a little change of SSOV structure. According to Kasma et al.(2008), the potential fishing ground area for ALB at coordinate $11-16^{\circ} \mathrm{S}$ and $106-121^{\circ} \mathrm{E}$ in Indian Ocean has a primary productivity between 73 $\mathrm{mg} \mathrm{C} / \mathrm{m}^{2} /$ day to $732 \mathrm{mg} \mathrm{C} / \mathrm{m}^{2} /$ day and sea surface temperature $24-30^{\circ} \mathrm{C}$.

\section{CONCLUSION}

The most significant influence of SSOV is obtained at depth of $291 \mathrm{~m}$ of ALB swimming layer with coefficient correlation $(r)$ of 0.934 and determination coefficient $\left(R^{2}\right)$ of 0.872 . A little change of SSOV would be followed by a significant change of ALB catches. This work suggests that temperature, dissolved oxygen, salinity and the availability of prey would be key factors for ALB catches at depth of $291 \mathrm{~m}$.

\section{ACKNOWLEDGEMENT}

I would like to thank to Ministry of Marine and Fisheries Affairs, The Agency of Research and Development Marine and Fisheries, Fisheries Research and Development Centre, and Research Institute for Tuna Fisheries for all financial support. I also would like to thanks to observers of Research Institute for Tuna Fisheries (RITF) Benoa Bali, Mr Abram Barata, Mr Andi Bachtiar, Mr Yusuf Affandi, Mr. Dian Novianto, Mr. Fathur Rochman, Mr Irwan Jatmiko, Mr. Ashadi, Mr. Hasan Syaiful Rizal, Mr. Adi Subagio. We also very grateful to DR Widodo Pranowo as Director of Marine and Coastal laboratory in Research and Development of Marine and Coastal Resource (RDMCR), and Budi Nugraha S.Pi, M.Si. as Director of Research Institute for Tuna Fisheries (RITF) for valuable input and comments.

\section{REFERENCES}

Barata, A., Novianto, D., \& Bahtiar, A. (2011). The distribution of tunas based on temperature and depth in Indian Ocean. Indonesian Marine Science Journal. Diponegoro University. Semarang. 16 (3), 165-170.

Bureau of technical supervision of the P.R of China.(1992). The Specification for Oceanographic Survey, Oceanographic Survey Data Processing (p. 68-70). (GB/T 12763.7-91). Standards press of China. 
Chen I. C., Lee P. F., \& Tzeng, N. W. (2005). Distribution of Albacore (Thunnus alalunga) in The Indian Ocean and Its Relation to Environmental Factor. Fish Oceanography. 14 (1), 71-80.

Cosgrove, R., Arregui,I., Arrizablaga, H., Goni, N., \& Sheridan, M. (2014). New insights to behavior of North Atlantic albacore tuna (Thunnus alalunga) observed with pop-up satellite archival tags. Fisheries Research.150, 89-99.

Domokos, R., Seki, M.P., Polovina., \& Hawn, J.J. D.R., (2007). Oceanographic investigation of the American Samoa albacore (Thunnus alalunga) habitat and longline fishing grounds. Fish. Oceanography.16, 555-572.

Foreman, T.J., (1980). Synopsis of biological data on the albacore tuna, Thunnus alalunga (Bonaterre, 1788), in the Pacific Ocean. In Synopses of biological data on eight species of scombroids, Ed.W. H. Bayliff. IATTC, La Jolla, California, 1770.

Graham, J.B., \& Dickson, K.A., (1981). Physiological thermoregulation in the albacore tuna (Thunnus alalunga). Physiol. Zool.54: 470-486.

Guntara, A. (2004). Structure community of vertically deep marine fish in Indian Ocean South of Cilacap (p. 102 ). Fisheries and Marine science. Bogor Agriculture Institute.

Hadi, S. (2004). Research methodology (p. 300-303). Andi Press. Yogyakarta.

IOTC. (2014). Executive summary of the status of the albacore tuna resource (p. 14). IOTC-2014SC17-ES01 Rev_1.

ISSF. (2014). Status of the world fisheries for tuna: Management of tuna stocks and fisheries, 2014. ISSF Technical Report 2014-05. International Seafood Sustainability Foundation, Washington, D.C., USA
Kasma, E., T. Osawa., \& Adnyana, I. W. S. (2008). Estimation of primary productivity for tuna in Indian Ocean. ECOTROPIC.2 (4), 86-91.

Lai, N. C., Graham, J. B., Lowell, W. R., \& Laurs, R. M. (1987). Pericardinal and vascular pressures and blood flow in the albacore tuna, Thunnus alalunga. Exp. Biol. 46, 187-192.

Latumeten, A. L., Purwanti, F., \& Hartoko, A.(2013). The analysis of relationship between sea surface temperature, chlorophyll-a of Modis satelite data and sub-surface temperature of Argo Float data to the number of tuna catches in Indian Ocean. Management of Aquatic Resource Journal. Diponegoro University. 2(2), 1-8.

Lehodey, P. (2002). SEPODYM development and application to skipjack population and fisheries. Oceanic Fisheries Programme, Secretariat of the Pacific Community, Noumea, New Caledonia. SCTB 15: Working Paper SKJ -2.

Nontji.(1993). Sea archipelago (p. 368 ). Reference book. Djambatan, Jakarta.

Nugraha, B., \& Triharyuni, S. (2009). The effect of temperature and hook depth of tuna longline to catch of tuna in Indian Ocean. Indonesian Fisheries Research Journal. Research Centre for Fisheries Management and Conservation. Indonesian Fisheries and Marine Affairs. 15 (3), 239-247.

Nybakken, J. W. (1992). Marine Biology. An ecological approach. Translated by Eidman, Koesobiono, D. G. Bengen, M. Hutomo, and S. Sukarjo.Press 2.Gramedia. Jakarta.

Song, L.M., Zhang,Y., \& Zhou, Y. (2007). The relationship between the thermocline and the catch rate of Thunnus obesus in the tropical areas of the Indian Ocean (p.13). In:Anonymous (Ed.). IOTC Proceeding-WPTT-14-rev1. 
Syamsuddin, M. L., Saitoh, S. I., Hirawake, T., Bachri,S., \& Harto, A.B.(2013). Effects of El Niño-Southern Oscillation events on catches of Bigeye Tuna (Thunnus obesus) in the Eastern Indian Ocean Off Java. Fish. Bull 111, 175-188.
Williams, A. J., Allain, V., Nicol, J. J., Evans, K. J., Hoyle, S. D., Dupoux, C., Vaorey, E., \& Dubosc, J. (2014). Vertical behavior and diet of albacore tuna (Thunnus alalunga) vary with latitude in the South Pacific Ocean. Deep-Sea Res. II (2014), http://dx.doi.org/10.1016/j.dsr2.2014.03.010i. 